\title{
Differentiation and structural decline in the leaves and bark of birch (Betula pendula) under low ozone concentrations
}

\author{
Madeleine S. Günthardt-Goerg, Rainer Matyssek, Christoph Scheidegger, and Theodor Keller \\ Swiss Federal Institute of Forest, Snow and Landscape Research, Zürcherstrasse 111, CH-8903 Birmensdorf ZH, Switzerland
}

Received March 11, 1992/July 28, 1992

Summary. Leaf and bark structure of a birch clone (Betula pendula Roth) continuously exposed to charcoal-filtered air or charcoal-filtered air plus ozone $(0.05,0.075$, $0.1 \mu 11^{-1}$ ) was investigated throughout one growing season. Increasing ozone dose influenced leaf differentiation by reducing leaf area and increasing inner leaf air space, density of cells developing into stomata, scales and hairs. When approximately the same ozone dose had been reached, macroscopical and microscopical symptoms appeared irrespective of the ozone concentration used during treatment. Structural decline began in mesophyll cells around stomatal cavities (droplet-like exudates on the cell walls), continued with disintegration of the cytoplasma and ended in cell collapse. Epidermal cells showed shrinkage of the mucilaginous layer (related to water loss). Their collapse marked the final stage of leaf decline. When subsidiary cells collapsed, guard cells passively opened for a transitory period before collapsing and closing. With increasing ozone dose starch remained accumulated along the small leaf veins and in guard cells. IIK-positive grains were formed in the epidermal cells. This contrasted with the senescent leaves, where starch was entirely retranslocated. Injury symptoms in stem and petiole proceeded from the epidermis to the cambium. Reduced tissue area indicated reduced cambial activity. In plants grown in filtered air and transferred into ozone on 20 August, injury symptoms developed faster than in leaves formed in the presence of ozone. Results are discussed with regard to $\mathrm{O}_{3}$ caused acclimation and injury mechanisms.

Key words: Ozone - Betula pendula - Leaf differentiation - Leaf and bark decline - Senescence

\section{Introduction}

Thorough understanding of tree function is inherently coupled with broad knowledge of tree structure (Zimmermann and Brown 1971; Körner 1991), in particular for analysis of tree injury (Waring 1987). Environmental conditions influence a plant during every stage of ontogeny (differentiation, maturity, senescence; Tichà 1985; Eschrich et al. 1989). Structural changes may, therefore, be bioindications of environmental stress. Leaves are the main targets of ozone attack (Reich 1987); the mechanisms of air pollutants affecting woody plants, however, are little understood (Mooney and Winner 1988).

This study aims to elucidate the question as to whether ozone influences leaf differentiation. Do leaves formed under ozone fumigation react differently to further ozone impact than leaves formed under $\mathrm{O}_{3}$-free air? To what extent does $\mathrm{O}_{3}$-caused structural decline in leaves and bark differ from natural autumnal senescence? These questions are investigated here by means of light and scanning electron microscopy with the same birch individuals, which in preceding papers have been examined for $\mathrm{O}_{3}$-caused changes in leaf function and whole-plant growth (Matyssek et al. 1991, 1992; Scheidegger et al. 1991). The breakdown of leaf photosynthesis was found to be driven by structural collapse of leaf tissue, while carbon allocation changed resulting in less stem and root biomass relative to foliage area. Quite apart from their role in the functioning of the tree, structural changes may, in their own right, be bioindications of ozone stress, and perhaps reveal acclimation processes to ozone.

\section{Materials and methods}

Plants and fumigations. Cuttings of 1 birch clone (Betula pendula Roth) were grown in 10-1 pots (1 plant/pot, well supplied with water and nutrients) from 14 April through 1 November 1989. When transferred into field fumigation chambers on 16 May 1989 , the plants had $3 \mathrm{~cm}$ long shoots with 3 growing leaves. Plants were separated into 4 ozone treatments with 5 chambers each and 4 plants per chamber. The ozone concentrations were 0 (control, charcoal-filtered air, $\mathrm{O}_{3}<0.003$ ), 0.05 , 
Table 1. Ozone fumigation and number of leaves

\begin{tabular}{|c|c|c|c|c|c|}
\hline $\begin{array}{l}\text { Harvest } \\
\text { date }\end{array}$ & $\begin{array}{l}\text { Ozone } \\
\text { concentration } \\
\mu 11^{-1}\end{array}$ & $\begin{array}{l}\text { A } \\
\text { Number of } \\
\text { leaves formed } \\
\text { on main stem } \\
\text { mean } \pm S D\end{array}$ & $\begin{array}{l}\text { B } \\
\text { Ozone dose } \\
\mu \mathrm{I}^{-1} \\
\text { until completed } \\
\text { leaf growth }\end{array}$ & $\begin{array}{l}\text { C } \\
\text { Days } \\
\text { until completed } \\
\text { leaf growth }\end{array}$ & $\begin{array}{l}\text { D } \\
\text { Ozone dose } \\
\mu l \mathrm{l}^{-1} \mathrm{~h} \\
\text { until plant } \\
\text { harvest }\end{array}$ \\
\hline 12 July & $\begin{array}{l}0 \\
0.05 \\
0.075 \\
0.1\end{array}$ & $\begin{array}{l}21.4 \pm 0.5 \\
20.8 \pm 1.6 \\
19.0 \pm 3.5 \\
16.0 \pm 1.9^{*}\end{array}$ & $\begin{array}{r}0 \\
26 \\
45 \\
72\end{array}$ & $\begin{array}{l}21 \\
22 \\
25 \\
30\end{array}$ & $\begin{array}{r}0 \\
68 \\
94 \\
137\end{array}$ \\
\hline 8 August & $\begin{array}{l}0 \\
0.05 \\
0.075 \\
0.1\end{array}$ & $\begin{array}{l}29.6 \pm 2.5 \\
30.4 \pm 2.4 \\
29.0 \pm 1.0 \\
28.0 \pm 1.2\end{array}$ & $\begin{array}{r}0 \\
19 \\
28 \\
31\end{array}$ & $\begin{array}{l}19 \\
16 \\
16 \\
13\end{array}$ & $\begin{array}{r}0 \\
100 \\
140 \\
199\end{array}$ \\
\hline 22 September & $\begin{array}{l}0 \\
0.05 \\
0.075 \\
0.1 \\
0.1^{* *}\end{array}$ & $\begin{array}{l}39.2 \pm 1.1 \\
39.8 \pm 2.8 \\
32.6 \pm 1.1^{*} \\
30.2 \pm 4.5^{*} \\
39.0 \pm 4.0\end{array}$ & $\begin{array}{l}0 \\
19 \\
28 \\
31 \\
0-77^{\text {a }}\end{array}$ & $\begin{array}{l}19 \\
19 \\
- \\
- \\
19\end{array}$ & $\begin{array}{r}0 \\
154 \\
221 \\
307 \\
77\end{array}$ \\
\hline
\end{tabular}

* $t$-test, significantly different from control $(p<0.05)$

$0.1^{* *}$ plants transferred from filtered air to $0.1 \mu 11^{-1}$ ozone on 20 August

a only 9 youngest leaves formed in ozone fumigation

Table 2. Correlations between morphological data and ozone dose (A, E), ozone concentration (B), harvest date (C), or macroscopical injury symptom (D)

\begin{tabular}{|c|c|c|c|c|c|c|}
\hline & & $\begin{array}{l}\text { A } \\
\text { Ozone dose } \\
\text { until } \\
\text { completed } \\
\text { leaf growth }\end{array}$ & $\begin{array}{l}\text { B } \\
\text { Ozone } \\
\text { concen- } \\
\text { tration }\end{array}$ & $\begin{array}{l}\text { C } \\
\text { Date } \\
\text { of } \\
\text { harvest }\end{array}$ & $\begin{array}{l}\mathrm{D} \\
\text { Injury } \\
\text { symptom }\end{array}$ & $\begin{array}{l}\text { E } \\
\text { Ozone dose } \\
\text { until harvest } \\
\text { of individual } \\
\text { leaf }\end{array}$ \\
\hline Measured individual & leaves & & & & & \\
\hline Leaf area & 102 & -0.69 & -0.57 & 0.57 & & \\
\hline Width of leaf blade & 84 & -0.53 & & 0.52 & & \\
\hline Density of hairs + scales & 53 & 0.65 & 0.55 & -0.51 & & \\
\hline Leaf air space & 102 & 0.55 & 0.54 & & & 0.55 \\
\hline Mass of water /leaf area & 102 & & -0.59 & & -0.65 & -0.67 \\
\hline Leaf dry mass /leaf area & 102 & & & 0.75 & 0.77 & 0.68 \\
\hline Cross-sectioned & petioles & & & & & \\
\hline Xylem area & 21 & -0.61 & & 0.69 & & \\
\hline Cross sectioned & stems & & & & & \\
\hline Phloem + cortex & 9 & & -0.81 & & & \\
\hline periderm & 9 & & -0.76 & & & \\
\hline
\end{tabular}

Correlation coefficients shown are $>0.5$ and have significance levels $P<0.001$

0.075 , and $0.100 \mu \mathrm{l} \mathrm{I}^{-1}$. Ozone was generated from pure oxygen and added continuously to charcoal-filtered air. Five plants were transferred from the control treatment to the $0.1 \mu 11^{-1}$ ozone treatment on 20 August.

Macroscopical methods. Leaves from the main stem were harvested on 12 July, 8 August, 22 September and 1 November. All leaves larger than $1 \mathrm{~cm}^{2}$ were numbered to register their macroscopical injury by 6 classes: $0=$ no symptoms, green; $0.5=$ isolated light-green dots; $1=$ light-green dots spread over the whole leaf; $2=$ light-green or bonze-green leaf colour, isolated tiny black dots; $3=$ leaves with discolouration and small necrotic areas; and $4=$ shed leaves. Symptom 1 corresponds to ,early visual symptoms', and classes $2+3$ correspond to ,established injury "in the preceding papers (Matyssek et al. 1991, 1992). Ozone dose was calculated at each harvest date for the whole plants, for the time span of leaf area growth (Table 1 columns B, D), and for the time period until occurrence of the different macroscopical injury symptoms in individual leaves. Inner air space of 102 individual leaves was calculated according to Koike (1988). Leaf thickness was measured with a micrometer for soft material between 2 nd-order veins in each half of the central lamina. Leaf area was determined with a Delta-T areameter MK2. For each leaf, the ratio water mass: leaf area was calculated in relation to leaf dry mass: leaf area (,specific leaf weight', see Matyssek et al. 1991, 1992). 
Microscopical methods. Discs (diameter $=8 \mathrm{~mm}$, between 2nd-order veins) were excised from each half of the central lamina for light or scanning electron microscopy. Leaves of equal age were harvested at the same time from the different treatments.

For low-temperature scanning electron microscopy (LTSEM) leaf discs were excised into a humid chamber and immediately frozen in liquid nitrogen (samples mounted on aluminium stubs with $1 \%$ methylcellulose, methocel MC, medium viscosity, Fluka). The frozen specimens were transferred onto the preparation chamber of the cryopreparation unit SCU 020 (Balzers Union; Müller et al. 1991). Some of the samples were fractured with a microtome at $-120^{\circ} \mathrm{C}$ under high vacuum All specimens were partially freeze-dried in the preparation chamber at $-80^{\circ} \mathrm{C}$. After sputter coating with $15 \mathrm{~nm}$ gold, the specimens were transferred with a manipulator through the sliding valve unto the cold stage in a Philips SEM 515 (Scheidegger et al. 1991). Three photographs (magnification $230 \times$ ) were taken randomly from each leaf disc.

Other leaf discs for light microscopy were excised into methanol (bleaching and conservation), and dyed with IIK solution ( $2 \mathrm{~g} \mathrm{KI}$ and $1 \mathrm{~g}$ I in $100 \mathrm{ml}$ distilled water) to determine starch patterns and stomatal density. Stomata were counted at 10 randomly chosen disc positions of $0.3 \mathrm{~mm}^{2}$ area, each situated in intercostal fields. For starch digestion, discs were incubated $\left(2 \mathrm{~h}, 50^{\circ} \mathrm{C}\right)$ with amyloglycosidase $(4 \mathrm{mg} / \mathrm{ml})$ in acetate buffer ( $\mathrm{pH} 4.8$ ) or just in buffer as a control. Starch fluorescence was observed under ultraviolet light (filter $395-425 \mathrm{~nm}$ ).

Cross-sections ( $2.5 \mu \mathrm{m}$ thick, Sorval ultramicrotome MT-1) were made from other leaf discs after fixation in glutaraldehyde solution $(2.5 \%$ at $5^{\circ} \mathrm{C}$ ) and embedment in Technovit 7000 . Sections were stained with $1 \%$ acid fuchsin and $0.05 \%$ toluidine blue solution and investigated by light microscopy using phase contrast. Cross-sections from the middle part of the corresponding leaf petiole and stem internode were prepared in the same way (number of sectioned and measured individual leaves, petioles and stems see Table 2). The anatomical terminology used was according to Trockenbrodt (1990). Tissue areas were determined from photographs taken from the cross-sections, using the leaf area meter.

\section{Results}

\section{Leaf number and differentiation}

Compared with the control trees grown in filtered air, the total number of leaves formed on the main stem by 12 July (Table 1 column A) was reduced in trees fumigated with $0.1 \mu \mathrm{l}^{-1}$ ozone. By 8 August, leaf production in $0.1 \mu 11^{-1}$ had caught up with that of the other treatments, but subsequently new leaf formation practically ceased in the 0.1 and $0.075 \mu \mathrm{l} \mathrm{l}^{-1}$ treatments. Trees transferred from filtered air to the $0.1 \mu \mathrm{l}^{-1}$ ozone treatment on 20 August continued leaf formation at the same rate as trees in filtered air or under $0.05 \mu 11^{-1}$.

The ozone dose (concentration $\times$ time) until completed leaf extension growth increased, when leaf development was slow in early summer (Table 1 columns B, C). Throughout the growing season leaf differentiation did not depend on the total ozone dose applied to the whole plants (Table 1 column D), but on the ozone dose until individual leaf extension was complete. As this ozone dose increased, individual leaf area decreased (Fig. 1A), leaf air space increased (Fig. 1 B), and stomatal density on the lower leaf side (Fig. 1C) increased by almost a factor of 2. Density of scales, small hairs, (Fig. 2 A, B), epidermal cells, and veins was enhanced. The width of adaxial epidermis, palisade parenchyma (Fig. 2C, D), individual leaf blades, and the tissue area of the central petioles (Table 2 column A) decreased.
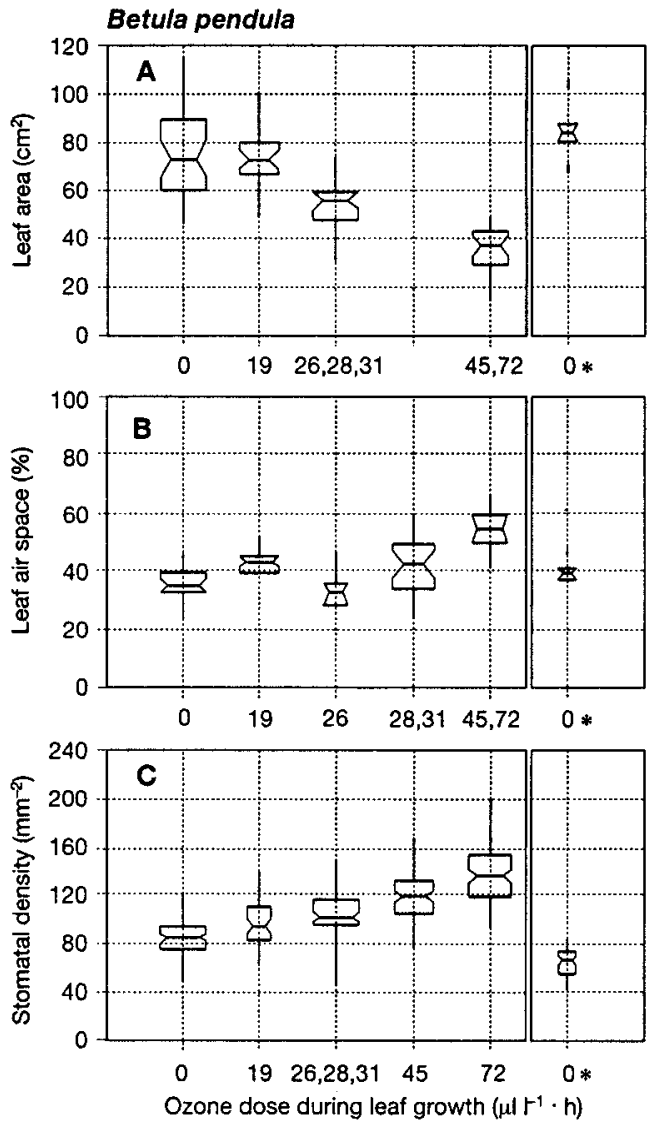

Fig. 1 A -C. Leaf differentiation in relation to ozone dose applied until completed area growth. A Leaf area; B Inner air space in a leaf; C Stomatal density (number of stomata per area of intercostal fields) on the lower leaf side (no stomata on upper side). * Denotes control leaves formed in filtered air before the plants were transferred to the $0.1 \mu \mathrm{ll}^{-1}$ ozone treatment on 20 August.

In "notched-box-and-whisker" plots (Tukey 1977; Statgraphics 1986) the vertical width of the box area covers $50 \%$ of the data, while the horizontal width represents the square root of the number of observations; the central horizontal line in the box area gives the median. The vertical lines ("whiskers") extending from the box upward to the absolute maximum or downward to the absolute minimum mark the upper or lower quartile of the data. The absolute extremes are shown as separate data points if their distance to the median exceeds the vertical box width by more than the factor $1 \frac{1}{2}$. The vertical width of the notches in the box area indicate the symmetrical $95 \%$ confidence range around the median (significance at $5 \%$ level is given if the notches of two boxes do not overlap). As seen in Fig. 2, quartiles can be closely crowded to the box (no whiskers), and confidence ranges can exceed the distance to the absolute extremes

The above mentioned parameters were also correlated with ozone concentration or harvest date (Table 2 columns B and C). All parameters were independent of macroscopical leaf injury symptoms (Table 2 column D), and all except leaf air space were independent of total ozone dose until harvest of individual leaves (Table 2 column E). Differentiation was not altered by ozone in leaves that had completed extension growth in filtered air before being transferred into the $0.1 \mu 11^{-1}$ ozone treatment on 20 August (Figs. 1, 2). 

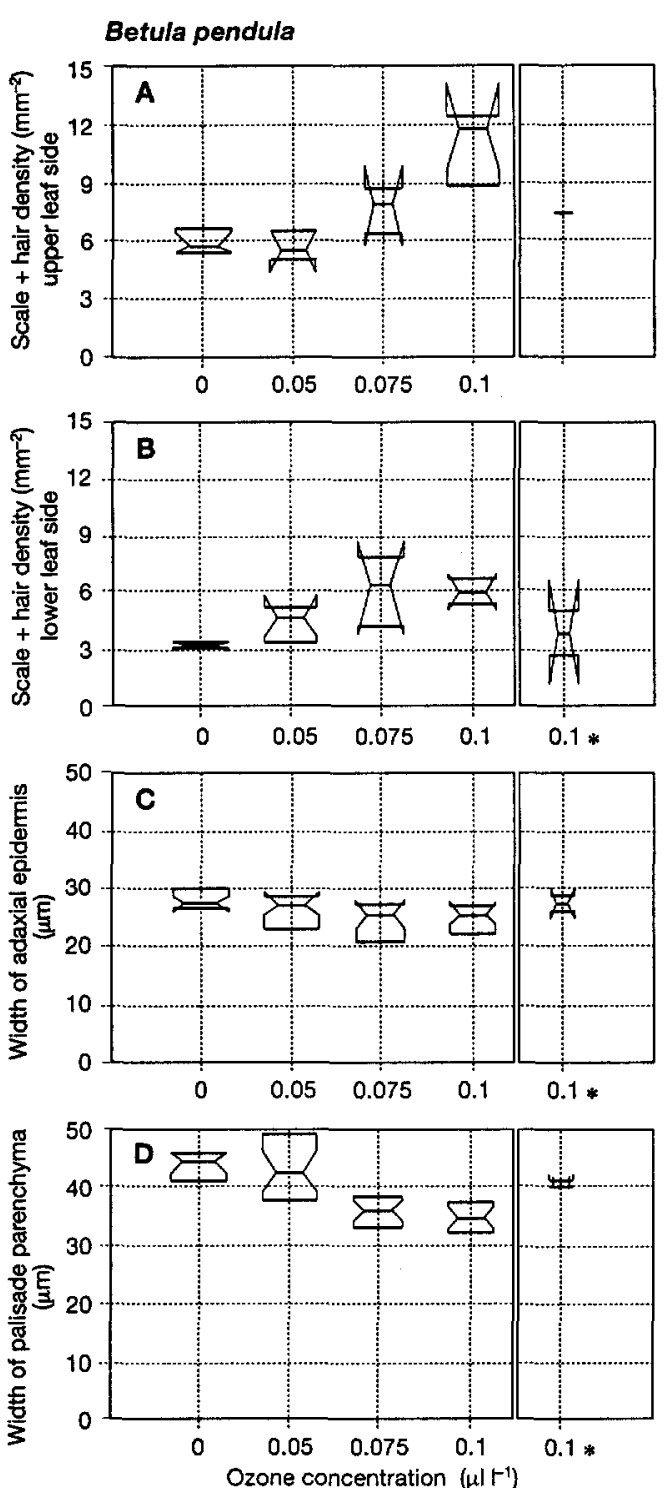

Fig. 2A-D. Leaf differentiation in relation to ozone concentration ("notched-box-and -whisker" plots as in Fig. 1).

$\mathbf{A}$ and $\mathbf{B}$, Number of peltate scales and hairs in intercostal fields; $\mathbf{C}$ and D, Microscopical measurements in sections integrated over a $309 \mu \mathrm{m}$ distance in intercostal fields without small leaf veins (4 measurements/leaf); $\mathbf{C}$, Width of upper epidermal cell layer; and $\mathbf{D}$, Width of palisade cell layer. * as in Fig. 1

\section{Symptoms of structural decline in leaf laminae}

In the different ozone concentrations and exposure times up to the harvest dates, macroscopical leaf symptom 1 (light-green dots) appeared as soon as the same range of ozone dose was reached (Fig. 3), but injury progress to necrosis (symptoms $2-4$ ) was accelerated in leaves that had developed in filtered air (Fig. 3, arrow).

Water mass per leaf area of control leaves was stable, but slightly lowered in ozonated leaves when isolated lightgreen dots (symptom 0.5 ) became visible, and then decreased drastically within symptom 3 as necroses enlarged (Fig. 4). Leaf dry mass per leaf area increased with leaf age and injury (Fig. 4).
Betula pendula

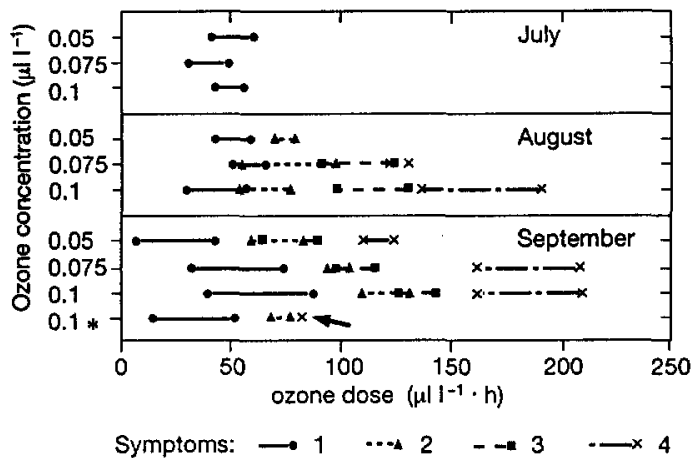

Fig. 3. Range of ozone dose generating macroscopic leaf injury in relation to ozone concentration and season. Symptom $1=$ light-green dots, symptom 2 = light-green or bronze-green leaf colour, tiny black dots, symptom 3 = leaves with discolouration and small brown necrotic areas, and symptom $4=$ shed leaves. Arrow indicates leaves, which after developing in the absence of ozone during differentiation, were shed early. ${ }^{*}$ as in Fig. 1

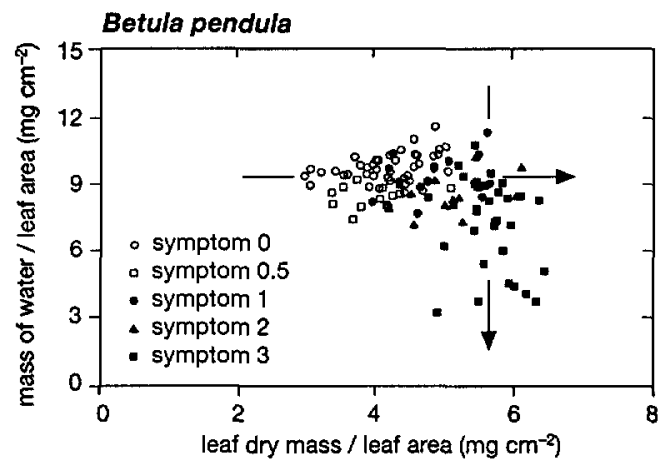

Fig. 4. Water mass per leaf area in relation to dry mass per leaf area. Each data point represents 1 leaf. Symptom $0=$ green, healthy leaves of the control; symptom $0.5=$ leaves with isolated light-green dots; symptoms $1-3$ as in Fig. 3

Inside declining ozonated leaves, mesophyll cells were disorganized, the ellipsoid structure of chloroplasts was disintegrated (Fig. 5B), nuclei shrunk, coloured dark, and cell walls appeared thickened. Beginning in the first injury stage (symptom 1), LTSEM showed unetchable dropletlike exudates (also present after critical point drying) on the cell walls inside the leaf (Fig. 6B) starting on cells around the stomatal cavities (Fig. 6C, D) and extending to the spongy parenchyma and the palisades. Droplet-like exudates preceded cell collapse and water loss, and stained the same way as cell walls (Fig. 5B).

With increasing ozone dose, epidermal cells showed shrinkage of the mucilaginous layer (Figs. 5, 6: $A=$ control, $\mathrm{B}=\mathrm{O}_{3}$-treated), leading to decreased epidermal width (Fig. 2C) in connection with injury symptoms $2-3$ and water loss (Fig. 4). Epidermal cells persisted longer than mesophyll cells (Fig. 6D), but started to collapse during the final stages of leaf decline (Fig. 7B, D). On the lower leaf side subsidiary cells collapsed before guard cells, consequently forcing the latter to open stomata widely in a transitory stage (Fig. 7D). When the guard cells had col- 

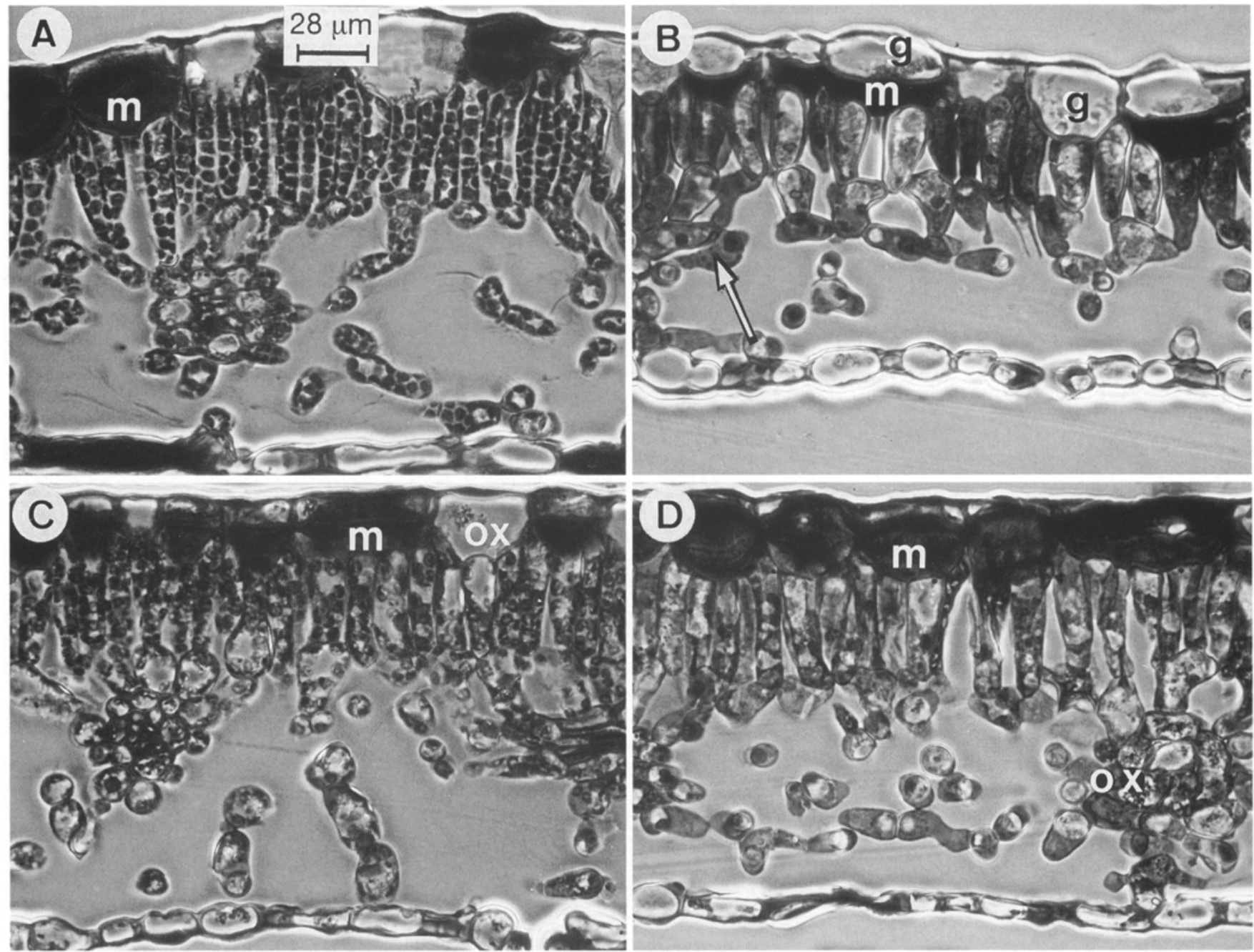

Fig. 5 A - D. Phase contrast microscopy. A, Control leaf. Chloroplasts are visible as black ellipsoids. Epidermal cells (especially of upper leaf side) have a mucilaginous thickening ( $m$, black) in the inner periclinal cell walls, which probably can store water (Boubier 1986; Mariani et al. 1988); B, Leaf with ozone injury symptom 2 . The mucilaginous layer is restricted to a compact mass, granular cell contents $(g)$ are visible in upper epidermal cells, cell compartments are disintegrating, walls of spongy parenchyma cells exhibit droplet-like exudates (arrow) (see also Fig. 6B); C, Control leaf in November, initial autumnal discolouration. $\mathrm{Ox}=$ crystals of oxalate; and $\mathbf{D}$, Control leaf in November, fully discoloured

lapsed, the stomata were closed, and the process of decline was terminated.

In November, yellowing senescent control leaves did not show thickened cell walls. The upper epidermal mucilage layer was not changed, cell content was not brownish, and chloroplast shape was still discernible (Fig. 5C, leaf with incipient, 5D with full yellow autumnal discolouration), as compared with cells injured by ozone (Fig. 5B). Fractured autumnal control leaves had turgescent cells until complete yellowing. The final collapsing process in the epidermis, however, resembled that in ozonated leaves (Fig. 7D).

With increasing ozone dose, starch production and translocation appeared to be reduced. During the course of a day mesophyll cells in control leaves were full of starch grains. In contrast, leaves with initial injury symptoms had less starch in the mesophyll and more in the guard cells. When control leaves showed a pale starch reaction (e.g. early morning, Fig. $8 \mathrm{~A}$ ), starch grains remained accumulated in bundle-sheath and adjacent mesophyll cells along small veins, and in guard cells of leaves with early signs of ozone injury (Fig. 8C). In addition ПIK-positive grains were formed in lower and upper epidermal cells of leaves with ozone injury symptoms $0.5-2$ (Fig. $8 \mathrm{C}$ ). With advancing injury (symptom 3, Fig. 8D) starch in mesophyll cells disappeared and remaining starch grains disintegrated into irregularly accumulated granules. In transferred plants newly formed leaves in September showed the above mentioned ozone-caused starch pattern, but decline in older leaves resembled that of senescent control leaves in November. In the latter control leaves starch had been entirely retranslocated, lastly from guard cells and small veins, and some grains in epidermal cells were coloured pale (Fig. 8B).

Chloroplast starch in mesophyll cells coloured blueblack (amylose) with the iodine reaction, whereas starch in 

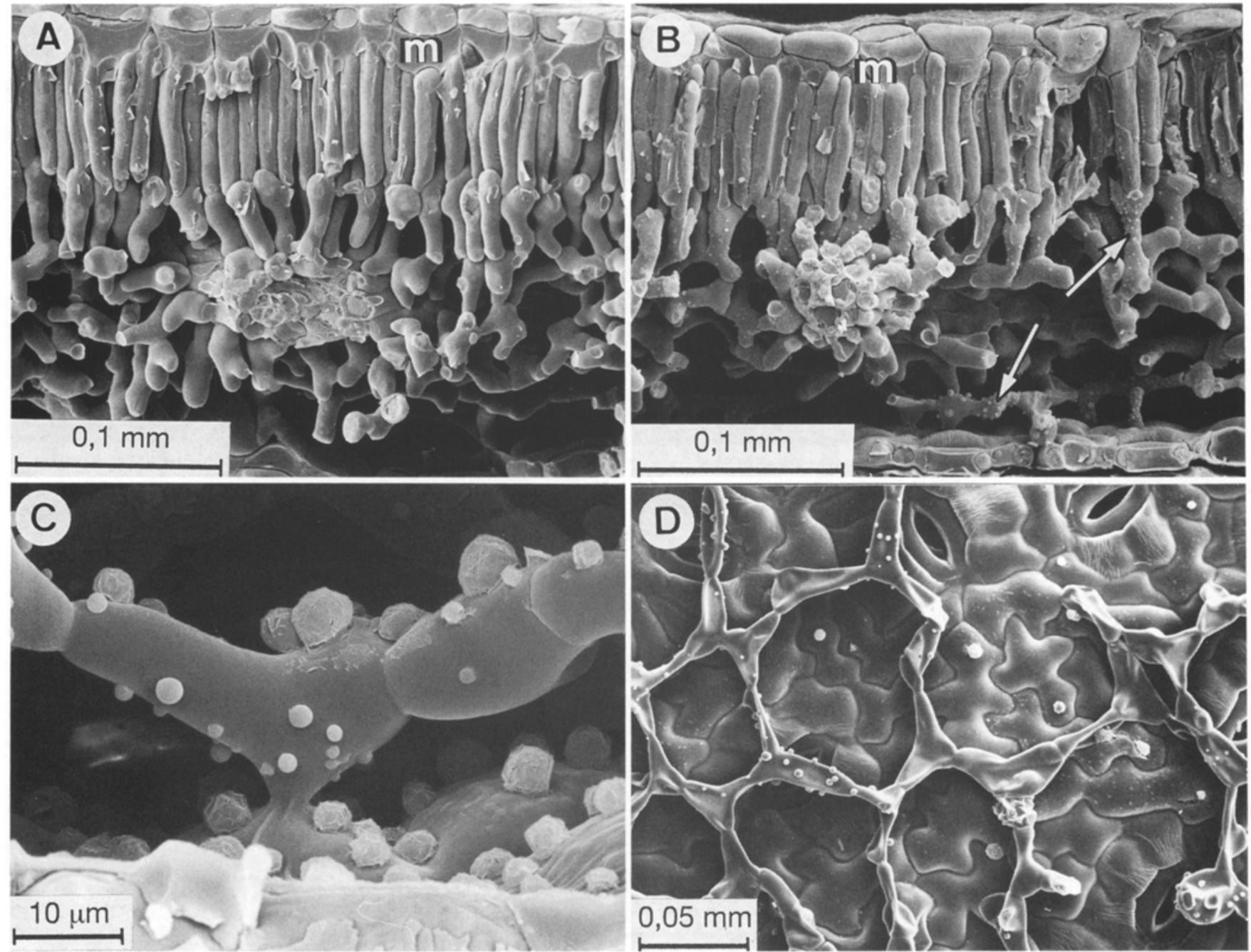

Fig. 6A-D. Low-temperature scanning electron microscopy (LTSEM) of fractured leaves ( $m=$ mucilaginous thickening as in Fig. 5). A, Control leaf; B, In leaves with ozone symptom 2, unetchable droplet-like exudates on the cell walls spread from the stoma to the spongy parenchyma (lower arrow) and to the palisade cells (upper arrow). Finally the mesophyll cells collapse; $\mathbf{C}$, Unetchable droplet-like exudates on the inner lower epidermis and adjacent spongy parenchyma cells; and D View of the inner surface of the lower epidermis in a leaf with symptom 3, after "fracturing away" the palisade parenchyma. Note collapsed spongy parenchyma cells attached to still turgescent epidermal cells

stomata and epidermis (ozonated leaves) coloured dark red-violet (amylopectin). This difference in starch type was verified with two additional methods. Chloroplast starch was experimentally digested by amyloglucosidase. The grains in stomatal openings and epidermal cells resisted this treatment and neither showed specific fluorescence at UV 395-425, as did chloroplast starch.

\section{Structural decline in petiole and stem bark}

In petioles of leaves with ozone injury symptoms, as in the stem internode above, phloem tissue showed distorted cells with contents detached from the walls, disintegrated, and finally collapsed cells (Fig. 9: $\mathrm{A}=$ control, $\mathrm{C}=\mathrm{O}_{3}-$ treated). With increasing ozone dose the rows of consecutive phloem-parenchyma and sieve elements were more and more interrupted by disintegrated or dead cells (Fig. 9C, corresponding control September, Novem- ber $=\mathrm{A}, \mathrm{B})$. The number of cells containing calcium oxalate (idioblasts), as counted in the petiole phloem tissue area, increased during the season (highest in November control leaves) but decreased with increasing leaf injury (Table 2 column $\mathrm{C}, \mathrm{D}$ ), whereas the number of idioblast per cortex tissue area was not altered. With increasing ozone dose, reduced cross-sectional tissue areas were measured (Table 2 columns A, B) indicating reduced cambial activity. Cell injury in the periderm (Fig. 9F, versus control D) preceded phloem injury and in the phloem tissue parenchyma cells showed injury before sieve elements. Deteriorating phellogen cells led to cessation of phellem and phelloderm production and, therefore, smaller periderm tissue diameter (Table 2 column B).

In transferred plants, vascular cambium and phellogen continued proliferation until September, in spite of enhanced leaf injury. However, phloem tissue was distorted with fewer brownish cells and more obliterated cells (indicative of a faster process of injury) than in plants fumi- 

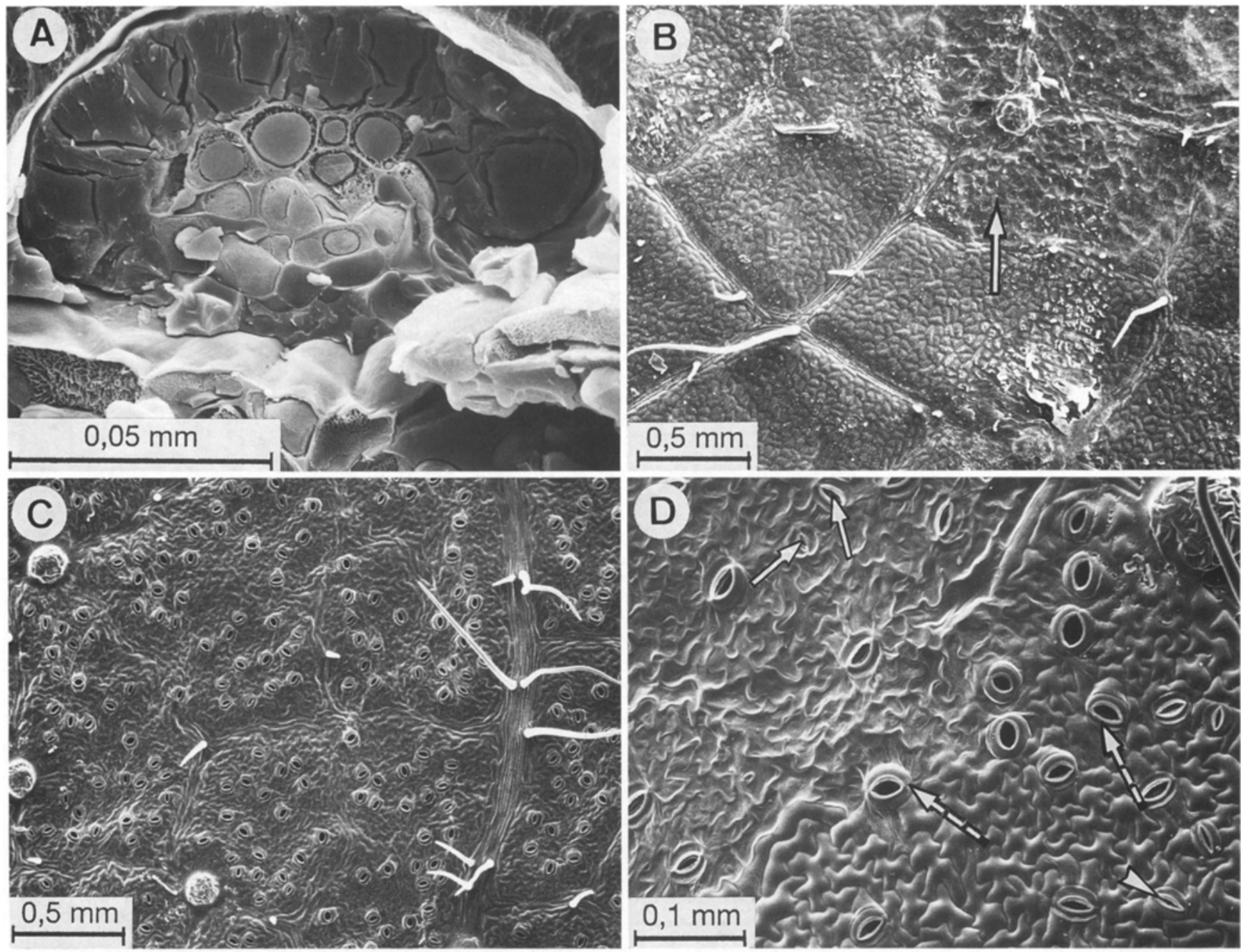

Fig. 7 A -D. LTSEM: A, Fractured peltate scale. Upper and lower leaf surfaces carry filiform hairs (length $0.3-6.5 \mathrm{~mm}$ ) on $2 \mathrm{nd}-\mathrm{order}$ veins, and small hairs $(0.05-0.3 \mathrm{~mm})$ on the fine veins, as well as multicellular scales with heads in shield-form on a very short, central, multicellular and multiseriate stalk, but appearing sessile (diameter $0.1 \mathrm{~mm}$ ); B, Upper epidermis with zone of collapsed cells (arrow) around a scale in a necrotic spot on a ozonated leaf with symptom 3; C, Lower epidermis (control) with stoma, scales and hairs; and D, Lower epidermis of an ozonated leaf with symptom 3. Arrow head points at normal, turgescent guard cells. When subsidiary cells collapse, guard cells open widely in a transitory stage (detached arrow) before they collapse individually and close the stoma (drawn arrow), although stomatal ledges may not touch

gated since April with a similar ozone dose. Periderm tissue was only injured in proportion to the applied ozone dose.

In November periderm in senescent control stems also showed aging features such as discoloured phellogen cells, but phelloderm cells were filled with storage substances, and cell content did not detach from the walls or start any process of decay (Fig. 9E).

\section{Discussion}

\section{Acclimation to ozone and detoxification}

As ozone dose increased during the period of leaf extension, leaf differentiation became increasingly altered (Figs. 1, 2). Fumigation with low ozone concentrations appeared to have influenced leaf differentiation even at an early ontogenetic stage, for example before stomata were formed. With the exception of reduced cross-sectional leaf width, leaf differentiation changed in the direction of xeromorphism, somewhat resembling sun leaves or leaf development under mild drought (Eschrich et al. 1989; Tichà 1985). Ozone responses in leaf differentiation might therefore partly be related to ozone-caused drought stress during the elongation phase. The hypothesis that changes in leaf differentiation had led to lowered ozone uptake and/or injury (acclimation to ozone) is supported by the high ozone sensitivity of transferred plants (Fig. 3, arrow). Possibly structural acclimation to ozone during development also occurs in needles, and might be a reason why they were less sensitive to ozone than needles fumigated after expansion growth (Landolt et al. 1989). The possibility of developmental acclimation may be applied further to trees growing at high elevation under continuously elevated ozone concentrations (Gehrig et al. 1991). Whether the expression of xeromorphic leaf structures, within the genetical possibilities, is controlled not only by light and 

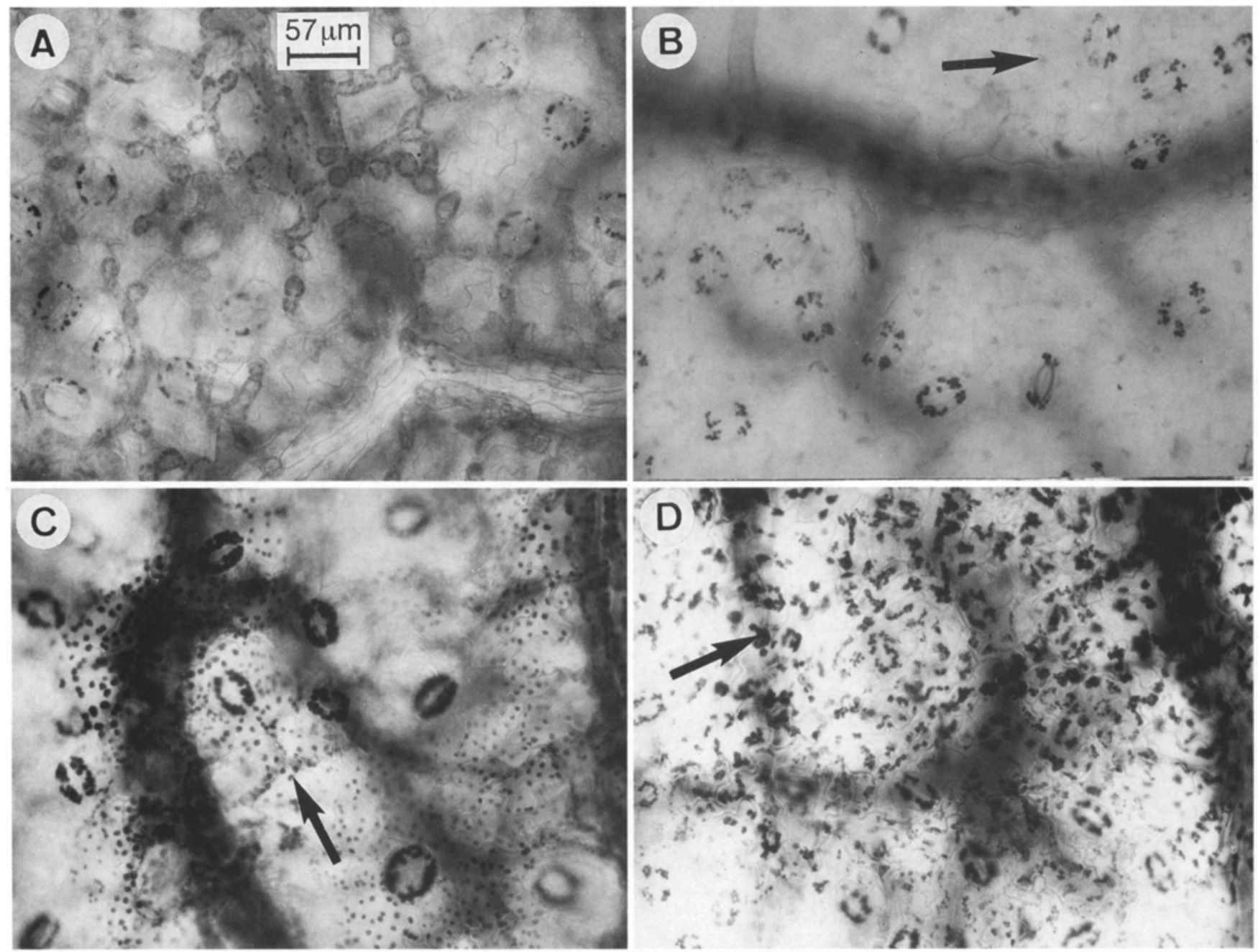

Fig. 8A -D. Light microscopy. Leaf discs stained with IIK solution to show the starch pattern. A, Control leaf; B, Control leaf with initial autumnal discolouration. During senescence starch was retranslocated first from the mesophyll, then from the guard cells and leaf veins. Arrow, pale grains in epidermal cells; $\mathbf{C}$, Leaf with ozone symptom 2. Starch stayed accumulated along minor leaf veins and in guard cells. IIK-positive grains were found in epidermal cells (arrow); see granular cell content in Fig. 5B; and D, Leaf with ozone symptom 3. Starch grains along veins, in guard cells, and in epidermal cells, appeared disintegrated into irregularly accumulated subunits (arrow), whereas mesophyll cells were without starch

temperature (Körner et al. 1989) but also modified by ozone needs investigation.

In fully expanded leaves uptake of gaseous air pollutants depends on stomatal conductance (Mooney and Winner 1988; Reich 1987). Ozone follows a coincident path with leaf gas exchange ( $\mathrm{CO}_{2}$ and water vapor) but is rapidly decomposed in the apoplast (Laisk et al. 1988). Radical reactions might take place with sulfide, amino, phenolic, or unsaturated $\mathrm{C}-\mathrm{C}$ groups, as shown in artificial systems (Hoigné 1988). Ozone-caused changes in apoplastic peroxidases and proteins may be interpreted as incipient injury (Castillo et al. 1991). On the other hand, plants have developed mechanisms to survive in photo-oxidative stress by enzymatical and chemical detoxification (Rennenberg 1988). Ozone-influenced processes, namely leaf differentiation, stomatal behavior (Matyssek et al. 1991; Scheidegger et al. 1991), phloem loading (indicated by increased leaf dry mass, Fig. 4), and cambial activity (Table 2 columns A, B, Fig. 9) imply the involvement of hormones
(Mansfield et al. 1990; Taylor et al. 1988; Brenner 1987). It is an open question whether hormonal action is directly influenced by ozone. Hormone receptor proteins at the external face of the plasmalemma (Napier and Venis 1991), transduce stress signals to the cytoplasma by sensing minute changes in apoplastic hormone concentration. They or the hormones themselves may constitute targets for ozone attack in their functional groups, but even temporary alterations in the fatty acid saturation stage of the plasmalemma (Lange et al. 1989) could lead to the observed ozone effects, whether they were induced directly by ozone or indirectly by hormonal message. In transferred plants without acclimation, the ozone injury process in the mature leaves progressed faster (Fig. 3) and phloem cells collapsed at unchanged cambium proliferation, indicating a decay process too fast to establish a hormonal message. In contrast, under ozone newly formed leaves of the same transferred plants showed structural acclimation. 


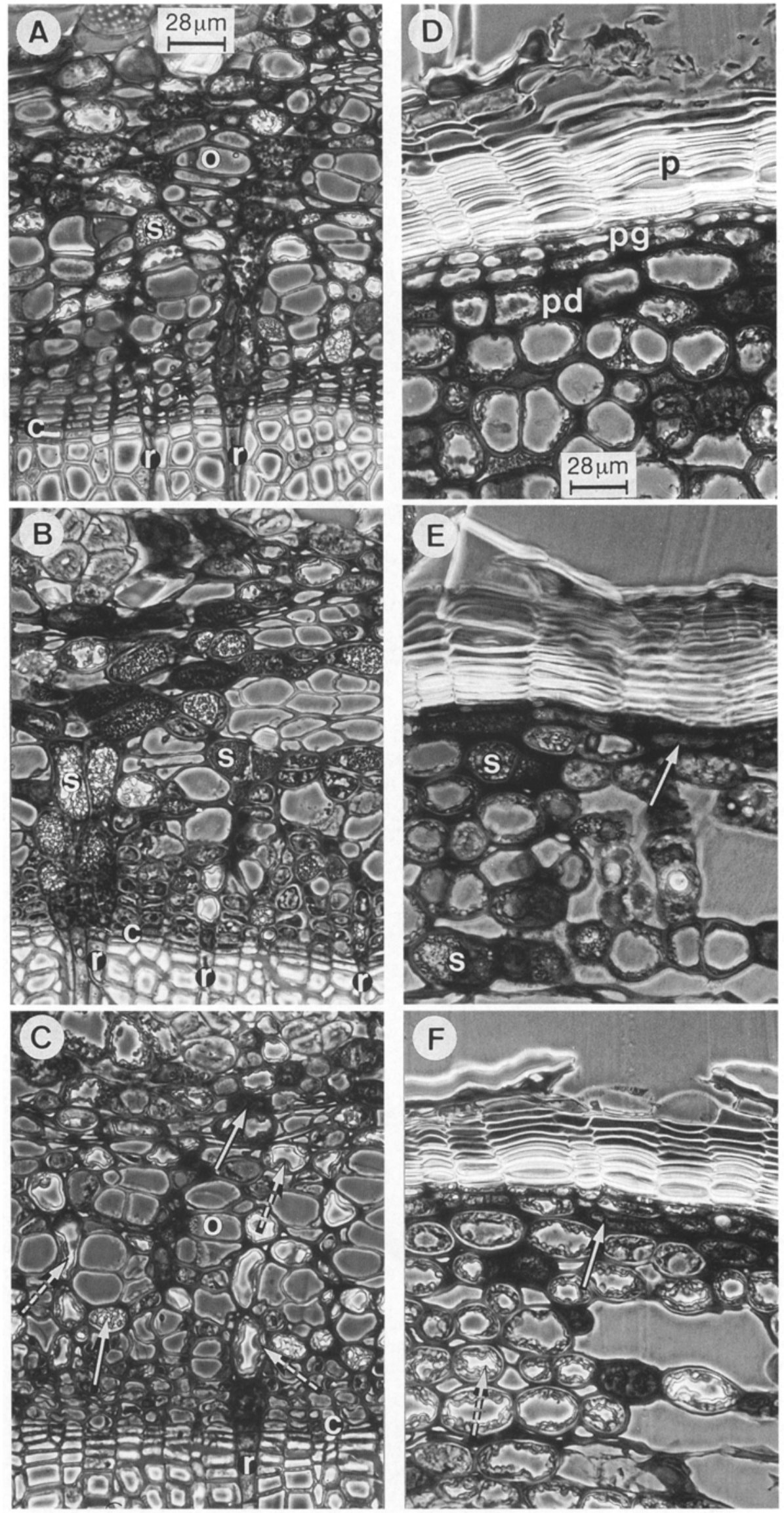

Fig. 9 A - F. Cross-sections through the stem at mid-stem height. Detached arrow $=$ cell content detached from the cell wall. Drawn arrow $=$ disorganized, brownish cell content. $c=$ vascular cambium, $p=$ phellem, $p d=$ phelloderm, $p g=$ phellogen, $o=$ portion of sieve plate, $r=$ ray, $s=$ storage cell. $\mathbf{A}$ and $\mathbf{D}$, Control plants with still green leaves harvested in September; $\mathbf{B}$ and $\mathbf{E}$ Control plants harvested in November, leaves with autumnal discoloration; $\mathbf{C}$ and F, Plants fumigated with $0.05 \mu \mathrm{O}_{3} \mathrm{I}^{-1}$ harvested in September. Leaves at mid-stem position had symptoms 2 and 3 . A-C, Conducting tissue. Phloem and youngest xylem parts separated by cambium cells. Cambium in $\mathbf{A}$ is bordered by young phloem and xylem cells, in $\mathbf{B}$ adjacent to storage cells on the phloem side, and in $\mathbf{C}$ adjacent to disorganized cells. Rays cross xylem and phloem in $\mathbf{A}$ and $\mathbf{B}$, but often end before reaching the phelloderm (interruption by damaged cells) in ozonated stems (C); and D-F, Periderm of samples shown in A-C. The phellem layer is reduced in $\mathbf{F}$, phellogen is brownish in $\mathbf{E}$ or with disintegrated cell content in $\mathbf{F}$, and phelloderm contains storage cells in $\mathbf{E}$ and declining cells in $\mathbf{F}$ 


\section{Ozone induced structural and functional decline}

Dose dependent appearance of macroscopical injury symptoms (Fig. 3) indicates that structural acclimation and detoxification must have been overstrained. Unetchable droplet-like exudates (Fig. 6B-D) showed that early injury occurred at the mesophyll cell wall, preceding structural alterations in the cytoplasm (Fig. 5B). Although assimilation rate declined in parallel with cell collapse, respiration rate remained unchanged when related to the total leaf area (Matyssek et al. 1991). It may be concluded that the respiration of the remaining cells may have been raised. In addition to the consumptional state of declining mesophyll cells (by increased energy cost and decreasing photosynthetical capacity) their increasing dry mass per leaf area (Fig. 4) indicates that more material (e. g. metabolites and cell wall material) remained deposited.

Because groups of mesophyll cells in $\mathrm{O}_{3}$-injured leaves collapsed before epidermal cells (Fig. 6D), a reduced leaf water mass resulted (Fig. 4) and leaf air space increased. In an early injury stage stomatal openings reacted with narrowing the stomatal pore (Matyssek et al. 1991). When, at the end of the declining process, epidermal cells collapsed (in particular subsidiary cells), guard cells passively and transitorily opened widely (Fig. 7D), before they themselves collapsed and thus closed the stomatal pore. This widely opened stage was also reported after $\mathrm{SO}_{2}$ and $\mathrm{NO}_{2}$ (Wright 1988), HF, or drought stress treatment (Zwiazek and Shay 1987).

Different types of starch and chloroplasts (Figs. 8, 5) indicate that carbohydrate metabolism in guard cells differs from that in mesophyll cells. Starch accumulates in the guard cells in the dark (closed stomata) when starch from photosynthetic parenchyma is translocated. Starch regulation between stomata and mesophyll, however, is poorly understood (Outlaw 1987), but when the transport of substances between mesophyll cells and apoplast declines, metabolic control of hydroactive stomatal movements can be disturbed. Uncoupling of stomata and mesophyll in ozonated leaves seems to relate to the accumulated starch in the guard cells (Fig. 8C) and is indicated by a decreasing water-use efficiency (Matyssek et al. 1991). Similarly accumulated starch in epidermal cells (including non-stomatal cells) indicates changed starch metabolism. Finally epidermal cells as uncoupled from mesophyll cells are the last to undergo decompartmentation with decomposition of the starch (Fig. 8D). Accumulation of starch along the fine leaf vein network (Fig. 8C) suggests problems in the mechanism of starch-sucrose turnover and the apoplastic phloem loading, whereas in senescent leaves starch is entirely retranslocated (Fig. 8B).

In the outer cortex tissue of petioles and stems (Fig. 9F), same as in leaves, cell injury may arise by ozone-induced radical reactions in the apoplast. Progressive cell injury follows a similar pathway across the bark as shown for water by Klemm (1989) using fluorescein as a polar dye. However adjacent specialized sieve elements resisted longer than parenchyma cells in a slow injury progress. Phloem structure may be affected by disturbed sink-source relations, inhibited phloem loading (Eschrich 1989), or declining phloem parenchyma cells. Particularly the first of these may explain why injured cells in phloem tissue occur in the stem internode above the first leaf with macroscopical injury. The decreasing number of idioblasts in injured phloem tissue (Table 2 column D) may reflect a reduced tissue metabolism and water transport.

Beside their measurable role in tree function, reported in preceding papers (Matyssek et al. 1991, 1992), structural changes indicated an acclimation to ozone and can provide detailed insight into $\mathrm{O}_{3}$-initiated decline processes. In addition, the timing and intensity of ozone exposure interact strongly with developmental processes in trees.

Acknowledgements. We thank Mr. U. Bühlmann, Mr. P. Bleuler, and Mr. A. Burkhart for tending the plants, Mr. I. Kälin for microtechnical-microscopical assistance, Mr. P. Hatvani for assistance in LTSEM and Dr. W. Landolt for the fumigation management, the method for enzymatical digestion of starch, and helpful revision of the manuscript. We are grateful for further language editing by the reviewer.

\section{References}

Boubier AM (1896) Recherches sur l'anatomie systématique des bétulacées-corylacées. Thèse Université de Genève Laboratoire de botanique (Chodat R) 3me série 6me fascicule: 10-21

Brenner ML (1987) The role of hormones in photosynthate partitioning and seed filling. In: Davies PJ (ed) Plant hormones and their role in plant growth and development. Nijhoff, Lancaster, pp 474-493

Castillo FJ, Ogier G, Greppin H (1991) Caractérisation de l'état sanitaire des arbres à l'aide d'indicateurs biochimiques et physiologiques. In: Stark M (ed) Lufthaushalt, Luftverschmutzung und Waldschäden in der Schweiz, Ergebnisse aus dem Nationalen Forschungsprogramm 14. Bd 5 Luftschadstoffe und Wald. VDF, Zürich, pp 135-141

Eschrich W (1989) Stofftransport in Bäumen. Schriften aus der Forstlichen Fakultät der Universität Göttingen und der Niedersächsischen Forstlichen Versuchsanstalt 94: 1-55

Eschrich W, Burchardt R, Essiamah S (1989) The induction of sun and shade leaves of the European beech (Fagus sylvatica L.): anatomical studies. Trees 3: $1-10$

Gehrig R, Bonvin JM, Tercier P, Jeannet P (1991) Spurengase. In: Schüpbach E (ed) Lufthaushalt, Luftverschmutzung und Waldschäden in der Schweiz, Ergebnisse aus dem Nationalen Forschungsprogramm 14. Bd 4 Meteorologie und Luftchemie in Waldbeständen. VDF, Zürich, pp 71-101

Hoigné J (1988) Bildung und chemische Bedeutung von Photooxidantien in der wässerigen Phase. In: PBWU (ed) Verteilung und Wirkung von Photooxidantien im Alpenraum. GSF-Bericht 17: 166-175

Klemm O (1989) Leaching and uptake of ions through above-ground Norway spruce tree parts. In: Schulze E-D, Lange OR, Oren R (eds) Forest decline and air pollution. Springer, Berlin Heidelberg New York, pp 210-237

Koike T (1988) Leaf structure and photosynthetic performance as related to the forest succession of deciduous broad-leaved trees. Plant Spec Biol 3: $77-78$

Körner CH (1991) Some often overlooked plant characteristics as determinants of plant growth: a reconsideration. Funct Ecol 5: 162-173

Körner CH, Neumayer M, Menendez-Riedl SP, Smeets-Scheel A (1989) Functional morphology of mountain plants. Flora 182: 353-383

Laisk A, Kull O, Moldau H (1989) Ozone concentration in intercellular air spaces is close to zero. Plant physiol 90: 1163-1167

Landolt W, Pfenninger I, Lüthy-Krause B (1989) The effect of ozone and season on the pool sizes of cyclitols in Scots pine (Pinus sylvestris). Trees 3: 85-88

Lange OL, Heber U, Schulze E-D, Ziegler H (1989) Atmospheric pollutants and plant metabolism. In: Schulze E-D, Lange OR, Oren R (eds) Forest decline and air pollution. Springer, Berlin Heidelberg New York, pp 238-273 
Mansfield TA, Hetherington AM, Atkinson CJ (1990) Some current aspects of stomatal physiology. Annu Rev Plant Physiol Plant Mol Biol 41: 55-75

Mariani P, Rascio N, Baldan B, Paiero P, Urso T (1988) Epidermal mucilage cells in leaves of Salix species. Flora 181: 137-145

Matyssek R, Günthardt-Goerg MS, Keller T, Scheidegger C (1991) Impairment of gas exchange and structure in birch leaves (Betula pendula) caused by low ozone concentrations. Trees 5: 5-13

Matyssek R, Günthardt-Goerg MS, Saurer M, Keller T (1992) Seasonal growth, $\delta^{13} \mathrm{C}$ in leaves and stem, and phloem structure of birch (Betula pendula) under low ozone concentrations. Trees 6: 69-76

Mooney HA, Winner WE (1988) Carbon gain, allocation, and growth as affected by atmospheric pollutants. In: Schulte-Hostede S, Darral NM, Blank LW, Wellburn AR (eds) Air pollution and plant metabolism. Elsevier, London, pp 272-287

Müller T, Guggenheim R, Düggelin M, Scheidegger C (1991) Freezefracturing for conventional and field emission low-temperature scanning electron microscopy: the scanning cryo unit SCU 020. J Microsc (Oxford) 161: 73-83

Napier RM, Venis MA (1991) From auxin-binding protein to plant hormone receptor? Trends Biochem Sci 2: 72-75

Outlaw WH Jr (1987) An introduction to carbon metabolism in guard cells. In: Zeiger E, Farquhar GD, Cowan IR (eds) Stomatal function. Stanford University Press, Stanford, pp 115-123

Reich PB (1987) Quantifying plant response to ozone: a unifying theory. Tree Physiol 3: 63-91
Rennenberg H (1988) Wirkungen von Photooxidantien auf Pflanzen. In: PBWU (ed) Verteilung und Wirkung von Photooxidantien im Alpenraum. GSF-Bericht 17: $360-370$

Scheidegger C, Günthardt-Goerg MS, Matyssek R, Hatvani P (1991) Low temperature SEM of birch leaves after exposure to ozone. J Microsc (Oxford) 161: 85-95

Statgraphics (1986) Statgraphics Statistical Graphics System by Statistical Graphics Corporation, Users Guide. STSC, Inc.

Taylor GE Jr, Ross-Todd BM, Gunderson CA (1988) Action of ozone on foliar gas exchange in Glycine max (L.) Merr. a potential role for endogenous stress ethylene. New Phytol 110: 301-308

Tichà I (1985) Onthogeny of leaf morphology and anatomy. In: Sestac Z (ed) Photosynthesis during leaf development. Task for vegetation science 11. Junk, Lancaster, pp 16-50

Trockenbrodt M (1990) Survey and discussion of the terminology used in bark anatomy. IAWA Bull 11: $141-166$

Tukey JW (1977) Exploratory data analysis. Addison-Wesley Publishing Company, Massachusetts

Waring RH (1987) Characteristics of trees predisposed to die. Bio Science 37: 569-574

Wright EA (1988) Some effects of low levels of sulfur dioxide and nitrogen dioxide on the control of water loss by Betula spp. In: Mathy P (ed) Air pollution and ecosystems. Reidel, Dordrecht, pp 760-765

Zimmermann MH, Brown CL (1971) Trees, structure and function. Springer, Berlin, Heidelberg New York

Zwiazek JJ, Shay JM (1987) Fluoride- and drought-induced structural alterations of mesophyll and guard cells in cotyledons of jack pine (Pinus banksiana). Can J Bot 65: 2310-2317 